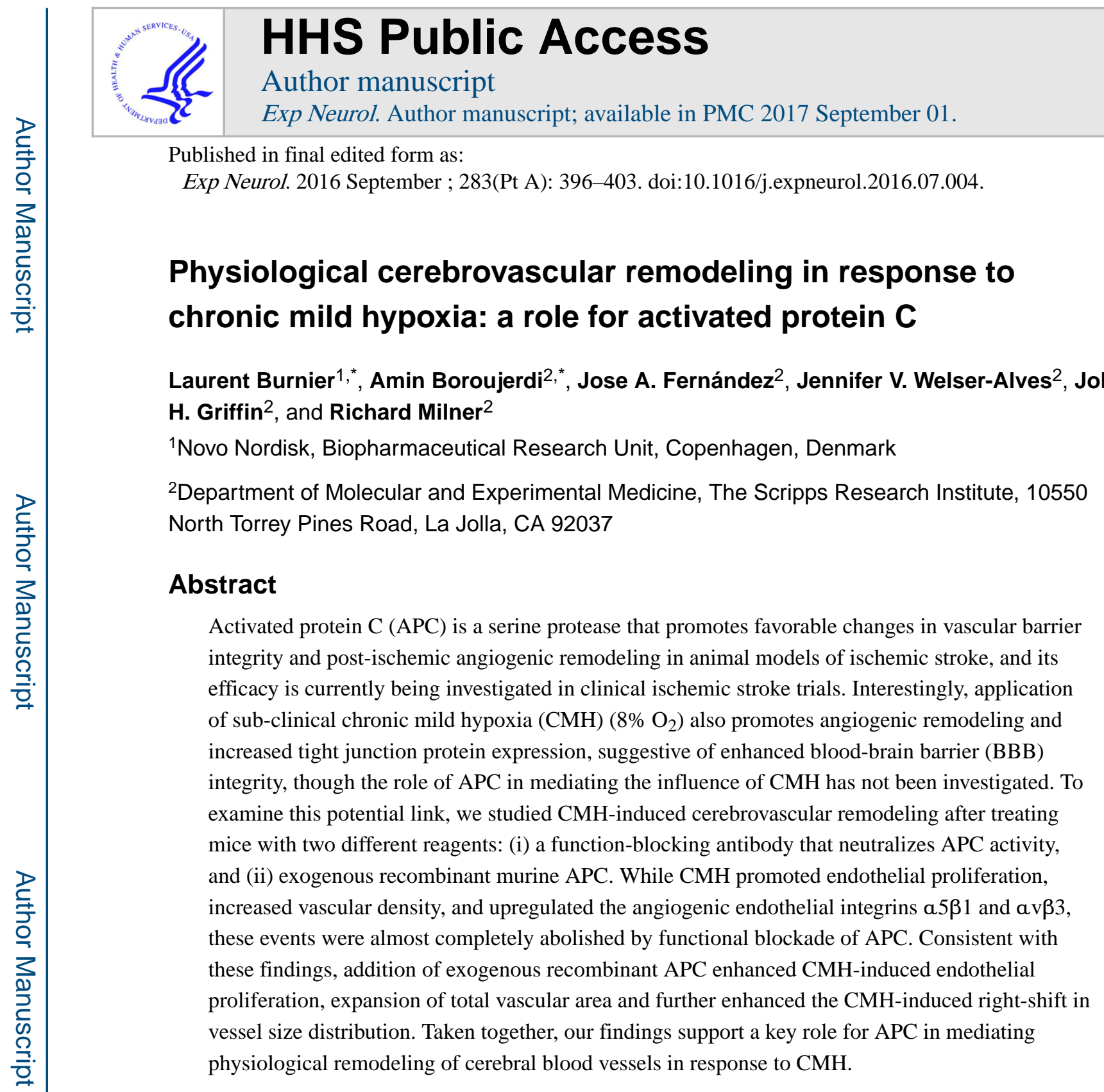

\title{
Keywords
}

Activated protein $\mathrm{C}$ (APC); chronic mild hypoxia (CMH); angiogenesis; vascular biology; endothelium; fibronectin; integrin

Corresponding author: Dr. Richard Milner at: Department of Molecular and Experimental Medicine, MEM-132, The Scripps Research Institute, 10550 North Torrey Pines Road, La Jolla, CA 92037. Tel: (858) 784-8569, Fax: (858) 784-8342, rmilner@ scripps.edu. * Made equal contributions to this study

\section{DISCLOSURE/CONFLICT OF INTEREST STATEMENT}

The authors declare no conflict of interest.

Publisher's Disclaimer: This is a PDF file of an unedited manuscript that has been accepted for publication. As a service to our customers we are providing this early version of the manuscript. The manuscript will undergo copyediting, typesetting, and review of the resulting proof before it is published in its final citable form. Please note that during the production process errors may be discovered which could affect the content, and all legal disclaimers that apply to the journal pertain. 


\section{INTRODUCTION}

Mild hypoxic conditioning $\left(8 \% \mathrm{O}_{2}\right)$ exerts protective effects in animal models of ischemic stroke and MS. Specifically, in mouse models of ischemic stroke, a short (2-4 hour) exposure to $8-10 \%$ hypoxia reduces the size of ischemic lesion and subsequent inflammation if ischemia occurs within 2-3 days of pre-conditioning (Dunn et al., 2012; Miller et al., 2001). In a more recent study, repeated intermittent exposure to mild hypoxia over several days extended this protection for several weeks (Stowe et al., 2011). Protection induced by mild hypoxic conditioning has also been demonstrated in the mouse model of MS, experimental autoimmune encephalomyelitis (EAE), resulting in reduced neurological deficit and associated neuroinflammation (Dore-Duffy et al., 2011). Significantly, in models of ischemic stroke and MS, at least part of this protection has been attributed to the ability of mild hypoxia to reduce leukocyte adhesion to and extravasation across the BBB (Dore-Duffy et al., 2011; Stowe et al., 2011), the cellular barrier that protects the sensitive neuropil from the potentially hazardous components of blood (Ballabh et al., 2004; Pardridge, 2003). Because of these findings, attention has focused on whether mild hypoxia might be mediating at least some of this protection via influencing the structure and function of cerebral blood vessels.

It is well established that mice exposed to chronic mild hypoxia $\left(\mathrm{CMH} ; 8 \% \mathrm{O}_{2}\right.$ over a two week period), show marked increases in vascularity (> $50 \%$ increased vascular density) in all areas of the brain (LaManna et al., 2004; LaManna et al., 1992; Milner et al., 2008a). Our studies have shown that this response involves angiogenic remodeling underscored by endothelial cell proliferation that is driven by upregulation of the fibronectin-a $5 \beta 1$ integrin signaling axis (Li et al., 2012; Milner et al., 2008a). Significantly, CMH-induced vascular remodeling is not just limited to capillaries; it also involves generation of new arterioles (arteriogenesis), consistent with the idea that mild hypoxia stimulates remodeling at all stages of the vascular tree (Boroujerdi et al., 2012). In addition to increasing vessel density, $\mathrm{CMH}$ also promotes increased endothelial expression of the tight junction proteins claudin-5 and zonula occludens-1 (ZO-1) in cerebral blood vessels (Li et al., 2010), implying that $\mathrm{CMH}$ also promotes BBB integrity.

Recent evidence reveals that neurological disorders such as ischemic stroke, multiple sclerosis (MS), amyotrophic lateral sclerosis (ALS) and many others share a common pathogenic triad that includes: (i) damage to the vascular barrier, (ii) neuronal injury, and (iii) neuroinflammation (Lo and Ning, 2016; Milner et al., 2008b; Zlokovic, 2011; Zlokovic and Griffin, 2011). In the hunt for novel therapeutic reagents that might show clinical promise in treating these neurological disorders, considerable attention has focused on activated Protein C (APC) (Griffin et al., 2015; Lyden et al., 2013). APC is a serine protease with systemic anticoagulant activity that is mediated by irreversible proteolytic inactivation of clotting factors Va and VIIIa with contributions from various cofactors (Esmon, 2012; Mosnier and Griffin, 2007; Rezaie, 2011). In addition to and independent of its anticoagulant activity, APC also exerts a number of direct cytoprotective effects that result in protection from the pathogenic triad; namely APC has been shown to increase the integrity of vascular barriers, reduce neuronal injury, promote neovascularization and neurogenesis, and attenuate neuroinflammatory responses (Cheng et al., 2003; Fernandez et al., 2005; Guo 
et al., 2004; Guo et al., 2013b; Joyce et al., 2001; Petraglia et al., 2010; Thiyagarajan et al., 2008; Wang et al., 2013a; Wang et al., 2013b). While these protective responses have thus far been extensively studied under pathological conditions, the role of APC in modulating events such as vascular remodeling under physiological conditions has not been investigated.

In light of the marked similarities between the influence of mild hypoxia and APC in promoting protective neurovascular responses, and the absence of studies examining the role of APC in mediating neurovascular remodeling under non-pathological conditions, the goal of this study was to determine whether some of the physiological vascular remodeling events induced by CMH are mediated by APC. To answer this question, we studied CMH-induced vascular remodeling responses in the brain after treating mice with two different complementary approaches, namely, a functional-blocking antibody that neutralizes endogenous APC activity, or infusion of exogenous recombinant murine APC, to see if these alternatives would affect $\mathrm{CMH}$-induced vascular remodeling.

\section{MATERIALS AND METHODS}

\section{Animals}

The studies described have been reviewed and approved by The Scripps Research Institute Institutional Animal Care and Use Committee. C57BL/6J mice were maintained under pathogen-free conditions in the closed breeding colony of The Scripps Research Institute (TSRI).

\section{Chronic Mild Hypoxia Model}

C57BL/6J male mice, $8-10$ weeks of age, were housed 4 to a cage, and placed into a hypoxic chamber (Biospherix, Redfield, NY) for periods up to 4 days maintained at $8 \% \mathrm{O}_{2}$. Control mice were kept in the same room under similar conditions except that they were kept at ambient oxygen levels (normoxia) for the duration of the experiment. Every few days, the chamber was briefly opened for cage cleaning and food and water replacement as needed.

\section{Protein $\mathrm{C}$ reagents}

Mouse recombinant activated protein $\mathrm{C}$ was produced and purified according to (Fernandez et al., 2005). Rat monoclonal antibody against mouse APC (SPC-54) was purified and characterized according to (Burnier et al., 2013). For some control experiments, the antiAPC antibody was boiled for $10 \mathrm{~min}$, centrifuged at 2,000 rpm and the supernatant collected was used for infusion.

\section{Administration of anti-APC blocking antibody and recombinant APC}

To investigate the impact of APC inhibition, 8-10 week old C57BL/6J male mice were anesthetized with inhalational $2 \%$ isoflurane in oxygen before receiving either a retro-orbital injection of $10 \mathrm{mg} / \mathrm{kg}$ of the function-blocking anti-APC rat monoclonal antibody SPC-54 (Burnier et al., 2013) (re-suspended in PBS pH 7.4 buffer, 100 $\mu \mathrm{L}$ ) or the same amount of heat-denatured antibody (as controls). 30 minutes following administration of the anti-APC antibody, mice were placed under hypoxic or normoxic conditions. To investigate the impact 
of exogenous APC, mice received intraperitoneal injections of either mouse recombinant APC $(0.8 \mathrm{mg} / \mathrm{kg}$ re-suspended in PBS pH 7.4 buffer, 100 $\mu \mathrm{L})$ or PBS vehicle (controls) one hour before hypoxic exposure and continued every 12 hours for the duration of the experiment, up to a maximum of 4 days.

\section{Immunohistochemistry and antibodies}

Immunohistochemistry was performed as described previously (Milner and Campbell, 2002) on $10 \mu \mathrm{m}$ frozen sections of cold phosphate buffer saline (PBS) perfused brains taken from mice subject to either normoxia (control) or hypoxic conditions. The following monoclonal antibodies were obtained from BD Pharmingen (La Jolla, CA): rat monoclonal antibodies reactive to: CD31 (clone MEC13.3) and the integrin subunit a5 (clone 5H10-27 (MFR5)) and hamster antibody to the $\beta 3$ integrin subunit (clone 2C9.G2). Other antibodies used included: hamster anti-CD31 (clone 2H8, Abcam, Cambridge, MA) and rabbit anti-Ki67 (Vector laboratories, Burlingame, CA). Secondary antibodies used included goat anti-rabbit Cy3 (Jackson Immunoresearch, Baltimore, PA) and anti-rat and anti-hamster Alexa Fluor 488 (Invitrogen, Carlsbad, CA).

\section{Image analysis}

Images were taken using a 20X objective on a Zeiss Imager M1.m microscope. All analysis was performed in the frontal lobe region of the brain. For each antigen, three images were taken per region at 10X or 20X magnification and the mean calculated for each subject over three different sections. All data analysis was performed using Perkin Elmer Volocity software (Waltham, MA). This includes quantification of total vessel (CD31-positive) area, numbers of CD31/Ki67 dual-positive cells, numbers of a 5 integrin and $\beta 3$ integrin-positive vessels and the size distribution of vessels. Each experiment was performed with 4-6 animals per condition, and the results expressed as the mean \pm SEM. Statistical significance was assessed by using the Student's $t$ test, in which $p<0.05$ was defined as statistically significant.

\section{RESULTS}

\section{Hypoxic-induced vascular remodeling in the brain is inhibited by functional blockade of endogenous APC}

To investigate the role of endogenous APC in cerebrovascular remodeling responses, 8-10 week old male $\mathrm{C} 57 \mathrm{BL} / 6$ mice were exposed to hypoxic $\left(8 \% \mathrm{O}_{2}\right)$ or control (normoxic) conditions for 4 days. Within each group, mice received either a retro-orbital injection of 10 $\mathrm{mg} / \mathrm{kg}$ function-blocking anti-APC antibody or the same amount of heat-denatured antibody as controls. Consistent with previous studies (LaManna et al., 2004; LaManna et al., 1992; Milner et al., 2008a), mice exposed to chronic mild hypoxia (CMH, 8\% $\mathrm{O}_{2}$ ) showed a strong angiogenic remodeling response throughout the brain, as demonstrated by marked endothelial proliferation and enhanced total vascular area. As shown in Figure 1, 4 days $\mathrm{CMH}$ significantly increased the number of proliferating endothelial cells (identified by CD31/Ki67 dual-positive cells) from $0.3 \pm 0.1$ cells per field of view (FOV) under control (normoxic) conditions to $9.7 \pm 0.8$ proliferating cells $(\mathrm{p}<0.005)$ under hypoxic conditions (quantified in Figure 1B). Over the same 4 day period, CMH increased the total vascular 
area (defined by CD31-positive area) to $125.4 \pm 2.7 \%$ of the control value, $\mathrm{p}<0.01$ ) (quantified in Figure 1C). Strikingly, APC blockade totally flattened the vascular remodeling response. Specifically, after 4 days $\mathrm{CMH}$, mice treated with the anti-APC antibody showed an almost total absence of endothelial proliferation (reduced from $9.7 \pm 0.8$ proliferating cells/FOV in control mice receiving the boiled antibody to $0.8 \pm 0.3$ proliferating cells in mice receiving the anti-APC antibody ( $\mathrm{p}<0.005)$ ( Figure 1B). This inhibitory effect on endothelial proliferation was reflected in a concomitant flattening of the increase in total vascular area, such that the anti-APC antibody decreased total vascular area from 125.8 $\pm 3.8 \%$ to $97.5 \pm 4.2 \%$ of the control normoxic value ( $\mathrm{p}<0.01$ ). Thus, APC blockade totally flattened the vascular remodeling response.

As we have previously described a marked upregulation of fibronectin and its cell surface receptor a $5 \beta 1$ integrin on angiogenic cerebral blood vessels (Li et al., 2010; Milner et al., 2008a), as well as an important role for a $5 \beta 1$ integrin in mediating hypoxic-induced angiogenesis (Li et al., 2012), we next examined whether APC functional blockade also inhibited upregulation of angiogenic integrins. Consistent with previous reports, 4 days $\mathrm{CMH}$ strongly increased endothelial expression of both fibronectin receptors a $5 \beta 1$ and av $\beta 3$ integrins on cerebral blood vessels (Figures 2 and 3). Quantification revealed that 4 days $\mathrm{CMH}$ promoted significant increases in the number of cerebral blood vessels positive for the a 5 integrin subunit (increased from $111 \pm 8.7$ vessels per FOV under control (normoxic) conditions to $247.7 \pm 8.5$ vessels per FOV following 4 days hypoxia, $\mathrm{p}<0.01$ ) and the $\beta 3$ integrin subunit (increased from $6.7 \pm 1.0$ vessels per FOV under control conditions to $119.3 \pm 8.0$ vessels per FOV following 4 days hypoxia, $\mathrm{p}<0.005)$. However, in CMH-treated mice, anti-APC blockade led to significant reductions in the number of blood vessels expressing the a 5 integrin (decreased from $247.7 \pm 8.5$ vessels per FOV under control conditions to $154.2 \pm 12.2$ vessels per FOV following the APC blockade, $\mathrm{p}<0.01$ ) and the $\beta 3$ integrin (decreased from $119.3 \pm 8.0$ vessels per FOV under control conditions to $41.3 \pm 3.2$ vessels per FOV following APC blockade, $\mathrm{p}<0.005)$.

\section{Recombinant murine APC enhances the hypoxic angiogenic response}

As functional blockade of endogenous APC almost totally inhibited hypoxic-induced vascular remodeling in the brain, we next examined whether addition of exogenous APC would enhance this cerebrovascular remodeling response. To investigate this, we evaluated the same parameters of vascular remodeling in response to $\mathrm{CMH}$, in the presence or absence of exogenous recombinant mouse APC $(0.8 \mathrm{mg} / \mathrm{kg})$, which was administered via the intraperitoneal route one hour before hypoxic exposure and continued every 12 hours for the duration of the experiment, up to a maximum of 4 days.

As shown in Figure 4, addition of exogenous APC enhanced the hypoxic-induced vascular remodeling response. Exogenous APC significantly increased the number of proliferating endothelial cells (identified by CD31/Ki67 dual-positive cells) observed after 4 days $\mathrm{CMH}$ from $9.1 \pm 1.2$ cells per FOV under control (PBS) conditions to $16.0 \pm 1.3$ proliferating cells per FOV in the exogenous APC group $(\mathrm{p}<0.01)$. A significant effect was also seen at the earlier (2.5 day) time-point, with the number of proliferating endothelial cells increased from $1.0 \pm 0.5$ cells per FOV under control (PBS) conditions to $4.7 \pm 1.0$ proliferating cells

Exp Neurol. Author manuscript; available in PMC 2017 September 01. 
per FOV in the exogenous APC group ( $\mathrm{p}<0.01)$. Consistent with the mitogenic effect on endothelial proliferation, exogenous APC significantly increased the total vascular area seen after 4 days $\mathrm{CMH}$, from $135 \pm 3.0 \%$ of the control (normoxic) value to $162.2 \pm 8.7 \%$ in APC-treated mice $(\mathrm{p}<0.05)$. Comparison of the number of cerebral vessels expressing the $a 5$ or $\beta 3$ integrins subunits failed to show any notable differences between control (PBS) and exogenous APC-treated conditions (not shown). Thus, under these experimental conditions, exogenous APC did not further boost endothelial expression of the angiogenic integrins studied.

To further investigate the ability of exogenous APC to enhance vascular remodeling in response to $\mathrm{CMH}$, we also examined the size distribution of vessels under the different experimental conditions. In a previous study, we made the important observation that in addition to increasing total vascular area, $\mathrm{CMH}$ also promotes a right-shift in the size distribution of blood vessels, resulting in a significantly increased number of large area vessels (Boroujerdi et al., 2012). Consistent with these findings, 4 days CMH produced a right-shift in vessel size distribution, resulting in increased numbers of large area vessels in the $200-500 \mu \mathrm{m}^{2}$ (increased from $45.3 \pm 2.3$ vessels/FOV under normoxic conditions to 61.7 \pm 4.3 vessels/FOV after 4 days $\mathrm{CMH} \mathrm{p}<0.02$ ) and $>500 \mu \mathrm{m}^{2}$ categories (increased from $10.3 \pm 1.5$ vessels/FOV under normoxic conditions to $22.7 \pm 2.0$ vessels/FOV after 4 days $\mathrm{CMH} \mathrm{p} \mathrm{<} \mathrm{0.05)} \mathrm{(Figure} \mathrm{5).} \mathrm{Interestingly,} \mathrm{over} \mathrm{the} \mathrm{same} 4$ day time-period, exogenous APC significantly increased the number of large $\left(>500 \mu \mathrm{m}^{2}\right)$ area vessels (increased from 22.7 \pm 2.0 vessels/FOV under control (PBS) conditions to $35.7 \pm 2.5$ vessels/FOV after 4 days $\mathrm{CMH} \mathrm{p}<0.02$ ), while at the same time, showing a trend towards decreasing the number of small area vessels in the $0-100 \mu \mathrm{m}^{2}$ and $100-200 \mu \mathrm{m}^{2}$ categories. Thus, exogenous APC enhanced the right-shift in vessel size distribution.

\section{DISCUSSION}

The observation that chronic mild hypoxia (CMH) induces profound vascular remodeling in the CNS was established more than 20 years ago (LaManna et al., 1992). Since that time, a number of studies have examined the mechanisms underlying this remodeling. New important roles for the HIF-1a, VEGF, angiopoietin-Tie2, and fibronectin-a5 $\beta 1$ integrin signaling axes were revealed in this process (Chavez et al., 2000; Dore-Duffy and LaManna, 2007; Kuo et al., 1999; Li et al., 2012; Milner et al., 2008a). Inspired by recent findings demonstrating a fundamental role for the serine protease APC in promoting cerebral angiogenesis under the pathological condition of ischemic stroke (Petraglia et al., 2010; Thiyagarajan et al., 2008), the goal of this study was to investigate whether APC might also be involved in mediating the physiological remodeling process triggered by exposure to $\mathrm{CMH}$. Intriguingly, our studies revealed that while $\mathrm{CMH}$ promoted endothelial proliferation, increased vascular density, and upregulated endothelial expression of the angiogenic integrins $\alpha 5 \beta 1$ and $\alpha v \beta 3$, these events were almost completely abolished by functional blockade of APC. Consistent with these findings, addition of exogenous recombinant APC enhanced endothelial proliferation, expansion of total vascular area and further enhanced the $\mathrm{CMH}$-induced right-shift in vessel size distribution. Taken together, these findings support an important role for APC in mediating the physiological remodeling of cerebral blood vessels in response to $\mathrm{CMH}$. 


\section{The Chronic mild hypoxia (CMH) model of vascular remodeling}

When rodents are exposed to $\mathrm{CMH}$, they undergo a number of systemic physiological adaptations in order to preserve blood flow and thus oxygen and energy supply to organs. These adaptations include increased ventilation rate and hematocrit, as well as reductions in body mass and core temperature (LaManna et al., 2004). In the CNS, cerebral blood flow is transiently increased and blood vessels undergo profound vascular remodeling, resulting in $50 \%$ increased vascular density across all areas of the CNS (LaManna et al., 1992). It is still unclear whether this $\mathrm{CMH}$ regimen induces any short-term or long-term harmful effects, either in the CNS or systemically. While it has been suggested that hippocampal neurons are particularly sensitive to hypoxia (Prass et al., 2003), a recent study found no damage to hippocampal neurons in mice exposed to intermittent mild hypoxia (Stowe et al., 2011). Indeed, most studies to date have demonstrated protective beneficial effects of $\mathrm{CMH}$, in that it stimulates beneficial adaptive responses that protect against subsequent potentially injurious stimuli. For example, hypoxic pre-conditioning has been shown to be highly effective at protecting against ischemic stroke in animal models (Dunn et al., 2012; Miller et al., 2001), as well as conferring resistance in the mouse model of multiple sclerosis, experimental autoimmune encephalomyelitis (EAE) (Dore-Duffy et al., 2011). Other studies have reported beneficial effects of mild hypoxia on other neurological parameters that include stimulation of hippocampal neurogenesis and protection against ethanol withdrawalinduced mitochondrial stress (Ju et al., 2012; Zhu et al., 2010). Furthermore, in all CMH experiments performed over the last 10 years, we have never observed any increased mortality or morbidity in CMH-treated mice, nor did we see any evidence of cell death in the CNS of these mice (Li et al., 2012).

\section{APC protects against hypoxic injury}

Transient hypoxia in human brain during cross-clamping for endarterectomy generates APC (Macko et al., 1999) and a number of studies have demonstrated that APC protects against hypoxic injury. APC reduced renal ischemia-reperfusion injury by restricting Y-box binding protein ubiquitination (Dong et al., 2015), rescued retinal cells from ischemic-induced death by blocking activation of caspase-3 -8 and -9 (Du et al., 2011), and reduced tissue hypoxia and apoptosis in traumatized skeletal muscle during endotoxemia (Gierer et al., 2007). APC has also been shown to attenuate microvascular injury induced by systemic hypoxia by reducing inflammatory leukocyte adherence, transmigration and vascular leakage in the small intestine (Bartolome et al., 2008). In the developing CNS, APC protects against hypoxic-induced hippocampal neuronal cell death, in part by reducing nitric oxide (NO) production (Yesilirmak et al., 2006). In the EAE model of MS, administration of APC reduced disease severity and suppressed Th1 and Th17 cytokine production in astrocytes and immune cells (Han et al., 2008). Another study showed that APC decreased activation and proliferation of astrocytes by thrombin, although APC treatment by itself did not cause any significant changes in astrocytes (Ivanova et al., 2014). Guo et al reported that APC strongly inhibits astrocyte differentiation in vitro in human neuroprogenitor cell populations (Guo et al., 2013a). Furthermore, administration of protein C (PC) zymogen in a sepsis model protected against astrocyte cell death (Memos et al., 2009). Consistent with this theme of APC mediating neuroprotection, our data show that in the hypoxic CNS, APC plays a key role in promoting physiological remodeling of cerebral blood vessels in response to $\mathrm{CMH}$. 


\section{Interactions between APC and integrin-mediated signaling}

In our study, we found that APC blockade significantly attenuated hypoxic induction of angiogenic integrins, suggesting that APC acts upstream of pathways that regulate integrin gene expression. While to our knowledge, this is the first study to document this type of regulation, previous studies have shown that APC can modulate integrin-mediated events directly, via its effect on the substrate PAR1 mediated by binding to its endothelial receptor, EPCR (Cao et al., 2010; Elphick et al., 2009). Binding studies using liquid chromatography analysis revealed that binding of the soluble APC receptor EPCR to neutrophils was partially dependent on the $\beta 2$ integrin Mac-1 (CD11b/CD18) (Kurosawa et al., 2000). Building on this finding, a more recent study documented that APC itself binds directly to neutrophil $\beta 1$ and $\beta 3$ integrins and strongly inhibits neutrophil migration (Elphick et al., 2009), consistent with its well-described anti-inflammatory role. Further analysis revealed that human APC contains the well-recognized integrin-binding motif Arg-Gly-Asp (RGD) and that mutation of this sequence in APC abolished the inhibition of neutrophil migration (Elphick et al., 2009).

\section{Conclusion}

In light of the marked similarities between the influence of chronic mild hypoxia (CMH) and APC in promoting protective neurovascular responses, the goal of this study was to determine whether some of the physiological vascular remodeling events induced by $\mathrm{CMH}$ are mediated by APC. Our studies revealed that hypoxic induction of endothelial proliferation, increased vascular density, and elevated endothelial expression of the angiogenic integrins $\alpha 5 \beta 1$ and av $\beta 3$ were almost completely abolished by functional blockade of APC. Consistent with these findings, addition of exogenous recombinant APC enhanced endothelial proliferation, expansion of total vascular area and further enhanced the $\mathrm{CMH}$-induced right-shift in vessel size distribution. Taken together, these findings support an important role for APC in mediating the physiological remodeling of cerebral blood vessels in response to $\mathrm{CMH}$. In future studies we plan to determine how APC mediates these effects by asking the following specific questions. First, at what level does APC regulate endothelial a $5 \beta 1$ integrin expression? Second, is this effect primarily mediated by PAR1, EPCR or other receptors? Third, does the APC-receptor complex associate with a5 $\beta 1$ integrin and thereby directly influence activation of the fibronectin- $\alpha 5 \beta 1$ integrin signaling axis? Further characterization of the effects of APC in chronic hypoxic conditions could generate new applications that might translate to the clinic.

\section{Acknowledgments}

This work was supported by a Postdoctoral Fellowship Award from the American Heart Association (AB) and by the NIH RO1 grants NS060770 (RM) and HL031950 and HL052246 (JHG). This is manuscript number 29325 from The Scripps Research Institute.

\section{LIST OF ABBREVIATIONS}
ALS amyotrophic lateral sclerosis
APC activated protein C 


$\begin{array}{ll}\text { BBB } & \text { blood-brain barrier } \\ \text { CMH } & \text { chronic mild hypoxia } \\ \text { EAE } & \text { experimental autoimmune encephalomyelitis } \\ \text { EPCR } & \text { endothelial protein C receptor } \\ \text { FOV } & \text { field of view } \\ \text { MS } & \text { multiple sclerosis } \\ \text { PAR1 } & \text { protease activated receptor } \\ \text { 1 ZO-1 } & \text { zonula occludens-1 }\end{array}$

\section{References}

Ballabh P, Braun A, Nedergaard M. The blood-brain barrier: an overview. Structure, regulation and clinical implications Neurobiology of Disease. 2004; 16:1-13. [PubMed: 15207256]

Bartolome S, Wood JG, Casillan AJ, Simpson SQ, O'Brien-Ladner AR. Activated protein C attenuates microvascular injury during systemic hypoxia. Shock. 2008; 29:384-387. [PubMed: 17693940]

Boroujerdi A, Welser-Alves J, Tigges U, Milner R. Chronic cerebral hypoxia promotes arteriogenic remodeling events that can be identified by reduced endoglin (CD105) expression and a switch in $\beta 1$ integrins. J Cereb Blood Flow Metab. 2012; 32:1820-1830. [PubMed: 22739620]

Burnier L, Fernandez JA, Griffin JH. Antibody SPC-54 provides acute in vivo blockage of the murine protein C system. Blood Cells Mol Dis. 2013; 50:252-258. [PubMed: 23385154]

Cao CZ, Gao YM, Li Y, Antalis TM, Castellino FJ, Zhang L. The efficacy of activated protein C in murine endotoxemia is dependent on integrin CD11b. Journal of Clinical Investigation. 2010; 120:1971-1980. [PubMed: 20458145]

Chavez JC, Agani F, Pichiule P, LaManna JC. Expression of hypoxic inducible factor 1a in the brain of rats during chronic hypoxia. J Appl Physiol. 2000; 89:1937-1942. [PubMed: 11053346]

Cheng T, Liu D, Griffin JH, fernandez JA, Castellino F, Rosen ED, Fukudome K, Zlokovic BV. Activated protein $\mathrm{C}$ blocks p53-mediated apoptosis in ischemic human brain endothelium and is neuroprotective. Nat Med. 2003; 9:338-342. [PubMed: 12563316]

Dong W, Wang H, Shazad K, Bock F, Al-Dabet MM, Ranjan S, Wolter J, Kohli S, Hoffmann J, Dhople VM, Zhu C, Lindquist JA, Esmon CT, Grone E, Grone HJ, Madhusudhan T, Mertens PR, Schluter $\mathrm{D}$, Isermann B. Activated protein $\mathrm{C}$ ameliorates renal ischemia-reperfusion injury by restricting Ybox binding protein-1 ubiquitination. J Am Soc Nephrol. 2015; 26:2789-2799. [PubMed: 26015455]

Dore-Duffy P, LaManna JC. Physiologic Angiodynamics in the Brain. Antioxidants and Redox Signaling. 2007; 9:1363-1371. [PubMed: 17627476]

Dore-Duffy P, Wencel M, Katyshev V, Cleary K. Chronic mild hypoxia ameliorates chronic inflammatory activity in myelin oligodendrocyte glycoprotein (MOG) peptide induced experimental autoimmune encephalomyelitis (EAE). Adv Exp Med Biol. 2011; 701:165-173. [PubMed: 21445784]

Du ZJ, Yamamoto T, Ueda T, Suzuki M, Tano Y, Kamei M. Activated protein C rescues the retina from ischemia-induced cell death. Invest Ophthalmol Vis Sci. 2011; 52:987-993. [PubMed: 20688738]

Dunn JF, Wu Y, Zhao Z, Srinivasan S, Natah SJ. Training the brain to survive stroke. PLoS One. 2012; 7:e45108. [PubMed: 23028788]

Elphick GF, Sarangi PP, Hyun YM, Hollenbaugh JA, Ayala A, Biffl WL, Chung HL, Rezaie AR, McGrath JL, Topham DJ, Reichner JS, Kim M. Recombinant human activated protein C inhibits integrin-mediated neutrophil migration. Blood. 2009; 113:4078-4085. [PubMed: 19244161] 
Esmon CT. Protein C anticoagulant system--anti-inflammatory effects. Semin Immunopathol. 2012; 34:127-132. [PubMed: 21822632]

Fernandez JA, Xu X, Liu D, Zlokovic BV, Griffin JH. Recombinant murine-activated protein C is neuroprotective in a murine ischemic stroke model. Blood Cells Mol Dis. 2005; 30:271-276. [PubMed: 12737945]

Gierer P, Hoffmann JN, Mahr F, Menger MD, Mittimeier T, Gradl G, Vollmar B. Activated protein C reduces tissue hypoxia, inflammation and apoptosis in tramtaized skeletal muscle during endotoxemia. Crit Care Med. 2007; 35:1966-1971. [PubMed: 17568327]

Griffin JH, Zlokovic BV, Mosnier LO. Activated protein C: biased for translation. Blood. 2015; 125:2898-2907. [PubMed: 25824691]

Guo H, Liu D, Gelbard H, Cheng T, Insalaco R, Fernandez JA, Griffin JH, Zlokovic BV. Activated protein $\mathrm{C}$ prevents neuronal apoptosis via protease activated receptors 1 and 3. Neuron. 2004; 41:563-572. [PubMed: 14980205]

Guo H, Zhao Z, Yang Q, Wang M, Bell RD, Wang S, Chow N, Davis TP, Griffin JH, Goldman SA, Zlocovic BV. An activated protein $\mathrm{C}$ analog stimulates neuronal production by human neural progenitor cells via a PAR1-PAR3-S1PR1-Akt pathway. J Neurosci. 2013a; 33:6181-6190. [PubMed: 23554499]

Han MH, Hwang SI, Roy DB, Lundgren DH, Price JV, Ousman SS, Fernald GH, Gerlitz B, Robinson WH, Baranzini SE, Grinnell BW, Raine CS, Sobel RA, Han DK, Steinman L. Proteomic analysis of active multiple sclerosis lesions reveals therapeutic targets. Nature. 2008; 451:1076-1081. [PubMed: 18278032]

Ivanova AE, Gorbacheva LR, Strukova SM, Pinelis VG, Reiser G. Activated protein C and thrombin participate in the regulation of astrocyte functions. Biochemistry (Moscow). 2014; 8:50-59.

Joyce DE, Gelbert L, Ciaccia A, DeHoff B, Grinnell BW. Gene expresion profile of antithrombotic protein $\mathrm{C}$ defines new mechansims modulating inflammation and apoptosis. J Biol Chem. 2001; 276:11199-11203. [PubMed: 11278252]

Ju X, Mallet RT, Metzger DB, Jung ME. Intermittent hypoxia conditioning protects mitochondrial cytochrome c oxidase of rat cerebellum from ethanol withdrawal stress. J Appl Physiol. 2012; 112:1706-1714. [PubMed: 22403345]

Kuo NT, Benhayon D, Przybylski RJ, Martin RJ, LaManna JC. Prolonged hypoxia increases vascular endothelial growth factor mRNA and protein in adult mouse brain. J Appl Physiol. 1999; 86:260264. [PubMed: 9887138]

Kurosawa S, Esmon CT, Stearns-Kurosawa DJ. The soluble endothelial protein C receptor binds to activated neutrophils: involvement of proteinase-3 and CD11b/CD18. J Immunol. 2000; 165:46974703. [PubMed: 11035113]

LaManna JC, Chavez JC, Pichiule P. Structural and functional adaptation to hypoxia in the rat brain. J Exp Biol. 2004; 207:3163-3169. [PubMed: 15299038]

LaManna JC, Vendel LM, Farrell RM. Brain adaptation to chronic hypobaric hypoxia in rats. J Appl Physiol. 1992; 72:2238-2243. [PubMed: 1629078]

Li L, Welser-Alves JV, van der Flier A, Boroujerdi A, Hynes RO, Milner R. An angiogenic role for the a $5 \beta 1$ integrin in promoting endothelial cell proliferation during cerebral hypoxia. Exp Neurol. 2012; 237:46-54. [PubMed: 22721769]

Li L, Welser JV, Dore-Duffy P, Del Zoppo GJ, LaManna JC, Milner R. In the hypoxic central nervous system, endothelial cell proliferation is followed by astrocyte activation, proliferation, and increased expression of the a6 $\beta 4$ integrin and dystroglycan. Glia. 2010; 58:1157-1167. [PubMed: 20544851]

Lo EH, Ning M. Mechanisms and challenges in translational stroke research. J Investig Med. 2016

Lyden P, Levy H, Weymer S, Pryor K, Kramer W, Griffin JH, Davis TP, Zlokovic B. Phase 1 safety, tolerability and pharmacokinetics of $3 \mathrm{~K} 3 \mathrm{~A}-\mathrm{APC}$ in healthy adult volunteers. Curr Pharm Des. 2013; 19:7479-7485. [PubMed: 24372304]

Macko RF, Killewich LA, Fernandez JA, Cox DK, Gruber A, Griffin JH. Brain-specific protein C activation during carotid artery occlusion in humans. Stroke. 1999; 30:542-545. [PubMed: 10066849] 
Memos N, Betrosian A, Messaris E, Boutsikou M, Kataki A, Chatzigianni E, Nikolopoulou M, Leandros E, Konstadoulakis M. Administration of human protein-C concentrate prevents apoptotic brain cell death after experimental sepsis. Brain Res. 2009; 1264:119-126. [PubMed: 19368819]

Miller BA, Perez RS, Shah AR, Gonzales ER, Park TS, Gidday JM. Cerebral protection by hypoxic preconditioning in a murine model of focal ischemia-reperfusion. Neuroreport. 2001; 12:16631669. [PubMed: 11409736]

Milner R, Campbell IL. Developmental regulation of $\beta 1$ integrins during angiogenesis in the central nervous system. Mol Cell Neurosci. 2002; 20:616-626. [PubMed: 12213443]

Milner R, Hung S, Erokwu B, Dore-Duffy P, LaManna JC, del Zoppo GJ. Increased expression of fibronectin and the a $5 \beta 1$ integrin in angiogenic cerebral blood vessels of mice subject to hypobaric hypoxia. Mol Cell Neurosci. 2008a; 38:43-52. [PubMed: 18343155]

Milner R, Hung S, Wang X, Berg GI, Spatz M, del Zoppo GJ. Responses of endothelial cell and astrocyte matrix-integrin receptors to ischemia mimic those observed in the neurovascular unit. Stroke. 2008b; 39:191-197. [PubMed: 18032737]

Mosnier LO, Griffin JH. The cytoproective protein C pathway. Blood. 2007; 109:3161-3172. [PubMed: 17110453]

Pardridge WM. Blood-brain barrier drug targetting: the future of brain drug development. Mol Med. 2003; 3:90-105.

Petraglia AL, Marky AH, Walker C, Thiyagarajam M, Zlokovic BV. Activated protein C is neuroprotective and mediates new blood vessel formation and neurogenesis after controlled cortical impact. Neurosurgery. 2010; 66:165-171. [PubMed: 20023547]

Prass K, Scharff A, Rusher K, Lowl D, Muselmann C, Victorov I, Kapinya K, Dirnagl U, Meisel A. Hypoxia-induced stroke tolerance in the mouse is mediated by erythropoietin. Stroke. 2003; 34:1981-1986. [PubMed: 12829864]

Rezaie AR. The occupancy of endothelial protein $\mathrm{C}$ receptor by its ligand modulates the par-1 dependent signaling specificity of coagulation proteases. IUBMB Life. 2011; 63:390-396. [PubMed: 21438119]

Stowe AM, Altay T, Freie AB, Gidday JM. Repetitive hypoxia extends endogenous neurovascular protection for stroke. Ann Neurol. 2011; 69:975-985. [PubMed: 21437933]

Thiyagarajan M, Fernandez JA, Lane SM, Griffin JH, Zlokovic BV. Activated protein C promotes neovascularization and neurogenesis in postischemic brain via protease-activated receptor 1 . $\mathrm{J}$ Neurosci. 2008; 28:12788-12797. [PubMed: 19036971]

Wang Y, Zhao Z, Chow N, Ali T, Griffin JH, Zlokovic BV. Activated protein C analog promotes neurogenesis and improves neurological outcome after focal ischemic stroke in mice via protease activated receptor 1. Brain Res. 2013a; 1507:97-104. [PubMed: 23438513]

Wang Y, Zhao Z, Chow N, Rajput PS, Griffin JH, Lyden PD, Zlokovic BV. Activated protein C analog protects from ischemic stroke and extends the therapeutic window of tissue-type plasminogen activator in aged female mice and hypertensive rats. Stroke. 2013b; 44:3529-3536. [PubMed: 24159062]

Yesilirmak DC, Kumral A, Tugyan K, Cilaker S, Baskin H, Yilmaz O, Duman N, Ozkan H. Effects of activated protein $C$ on neonatal hypoxic ischemic brain injury. Brain Res. 2006; 1210:56=62. [PubMed: 18420181]

Zhu XH, Yan HC, Zhang J, Qu HD, Qiu XS, Chen L, Li SJ, Cao X, Bean JC, Chen LH, Qin XH, Liu JH, Bai XC, Mei L, Gao TM. Intermittent hypoxia promotes hippocampal neurogenesis and produces antidepressant-like effects in adult rats. J Neurosci. 2010; 30:12653-12663. [PubMed: 20861371]

Zlokovic BV. Neurovascular pathways to neurodegeneration in Alzheimer's disease and other disorders. Nat Rev Neurosci. 2011; 12:723-738. [PubMed: 22048062]

Zlokovic BV, Griffin JH. Cytoprotective protein C pathways and implications for stroke and neurological disorders. Trends in Neurosci. 2011; 34:198-209. 


\section{Highlights}

- Studied role of APC in chronic mild hypoxia-induced cerebrovascular remodeling

- $\quad$ APC blockade flattened the hypoxic-induced vascular remodeling response

- $\quad$ APC block abolished increases in endothelial proliferation and vascular density

- $\quad$ APC block also abolished induction of angiogenic endothelial a $5 \beta 1 /$ av $\beta 3$ integrins

- $\quad$ Recombinant APC enhanced endothelial proliferation and expanded total vascular area 

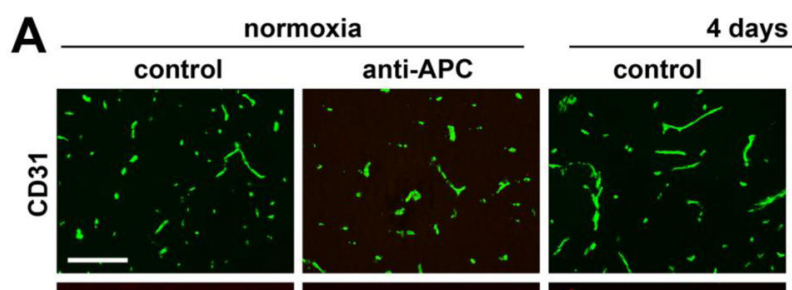

4 days hypoxia
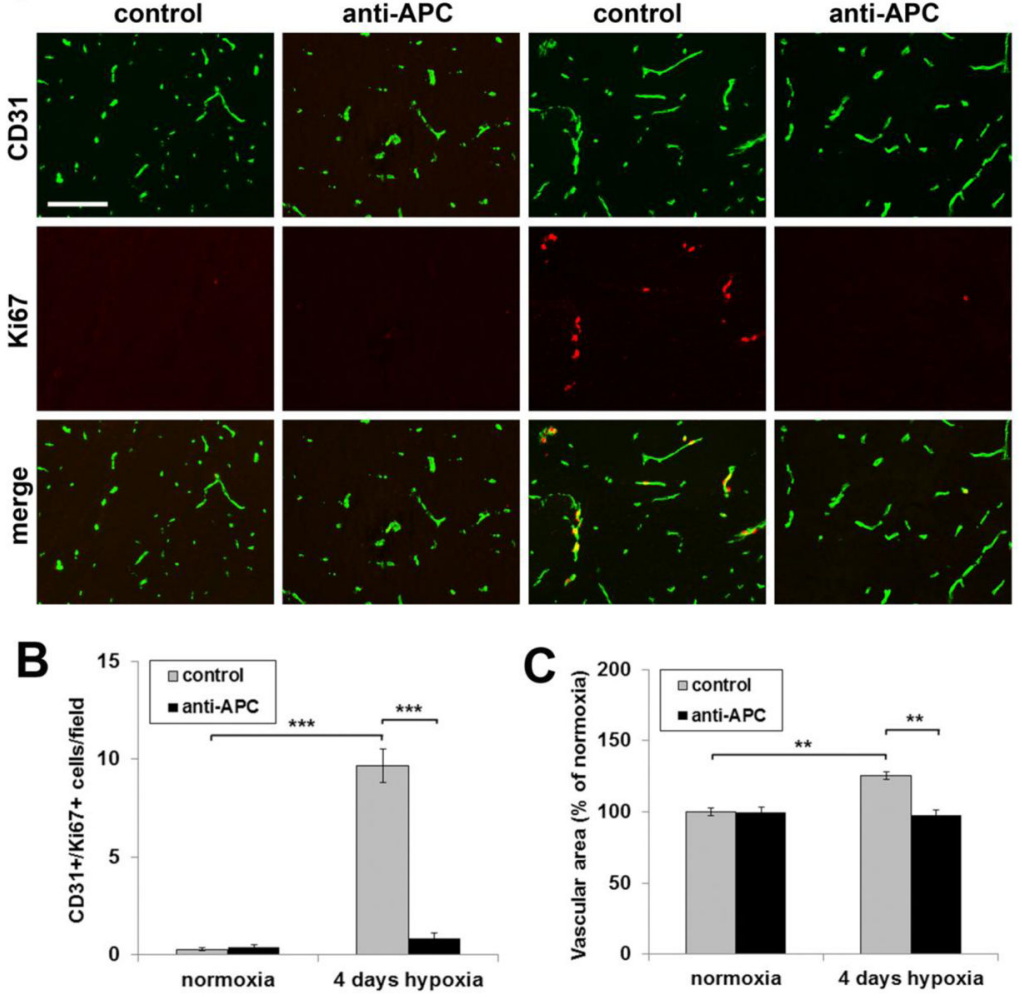

Figure 1.

Hypoxic-induced cerebrovascular remodeling is inhibited by functional blockade of endogenous APC. A. Dual-IF was performed on frozen sections of frontal lobe from mice exposed to 4 days normoxia or chronic mild hypoxia $(\mathrm{CMH})$ that had been injected with a monoclonal anti-APC antibody (SPC-54) or heat-denatured antibody (control) using antibodies specific for CD31 (AlexaFluor-488, green) or Ki67 (Cy3, red). Scale bar = $100 \mu \mathrm{m}$. B-C. Quantification of the number of CD31/Ki67dual-positive cells (B) or total vessel area (C). All experiments were performed with six animals per condition, and the results expressed either as the mean \pm SEM of dual-positive cells (B) or as the mean \pm SEM of the $\%$ change compared to normoxic conditions (C). Note that hypoxic-induced increases in endothelial cell proliferation and total vascular area were strongly inhibited by the antiAPC antibody. ** $\mathrm{P}<0.01, * * * \mathrm{P}<0.005$. 

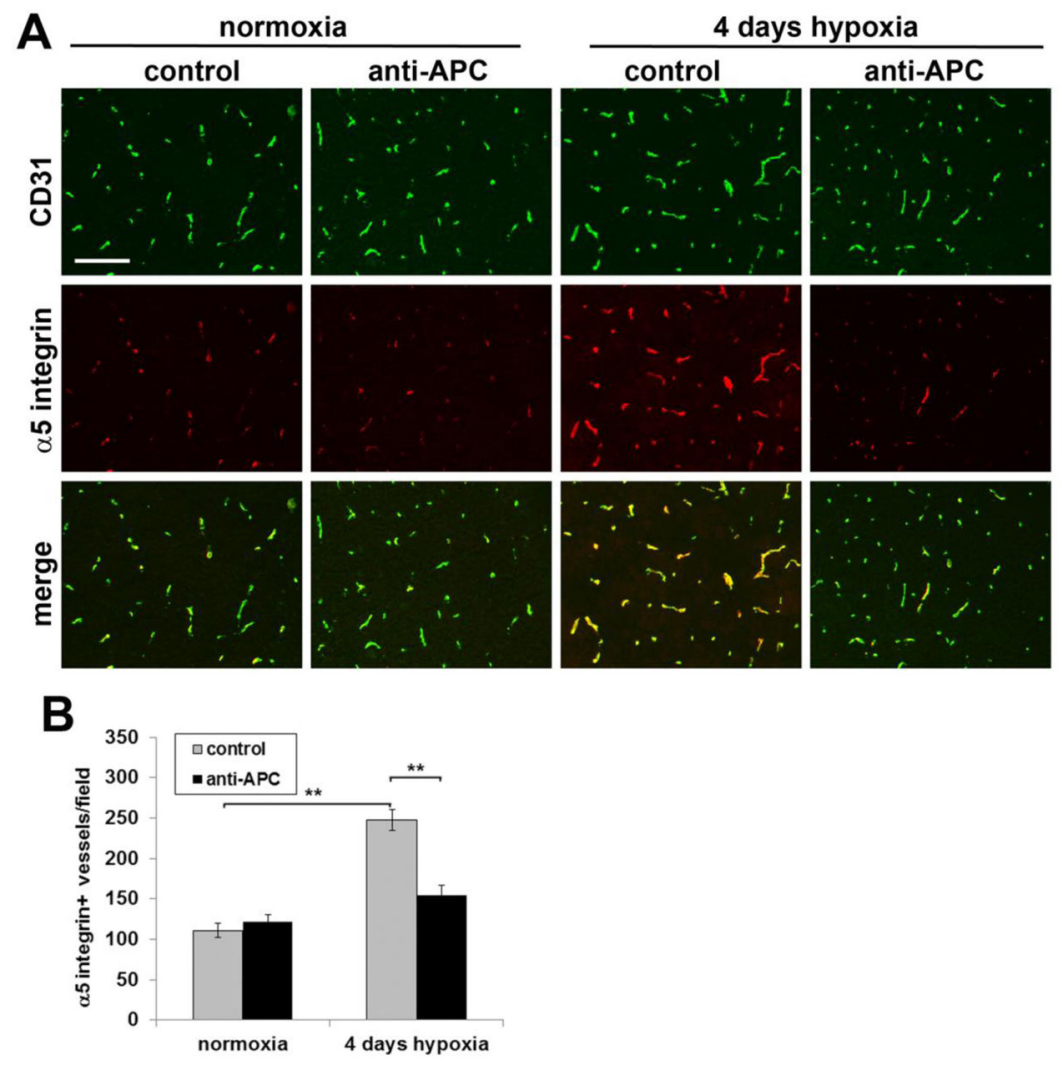

Figure 2.

Hypoxic-induced upregulation of endothelial a 5 integrin is inhibited by functional blockade of endogenous APC. A. Dual-IF was performed on frozen sections of the frontal lobe from mice exposed to 4 days normoxia or chronic mild hypoxia $(\mathrm{CMH})$ that had been injected with a monoclonal anti-APC antibody (SPC-54) or heat-denatured antibody (controls) using antibodies specific for CD31 (AlexaFluor-488, green) or a5 integrin (Cy3, red). Scale bar $=$ $100 \mu \mathrm{m}$. B. Quantification of the number of a 5 integrin-positive vessels per field. All experiments were performed with six animals per condition, and the results expressed either as the mean \pm SEM of a 5 integrin-positive vessels per field. Note that hypoxic-induction of endothelial a 5 integrin expression was strongly inhibited by the anti-APC antibody. ** $\mathrm{P}<$ 0.01 . 
A
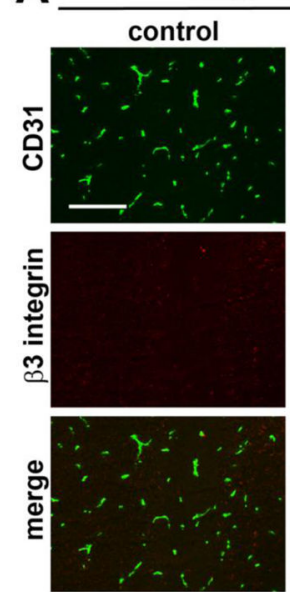

B 200
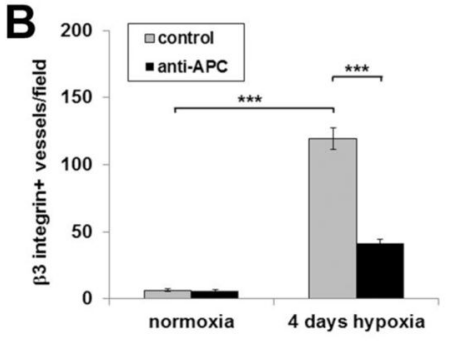

4 days hypoxia
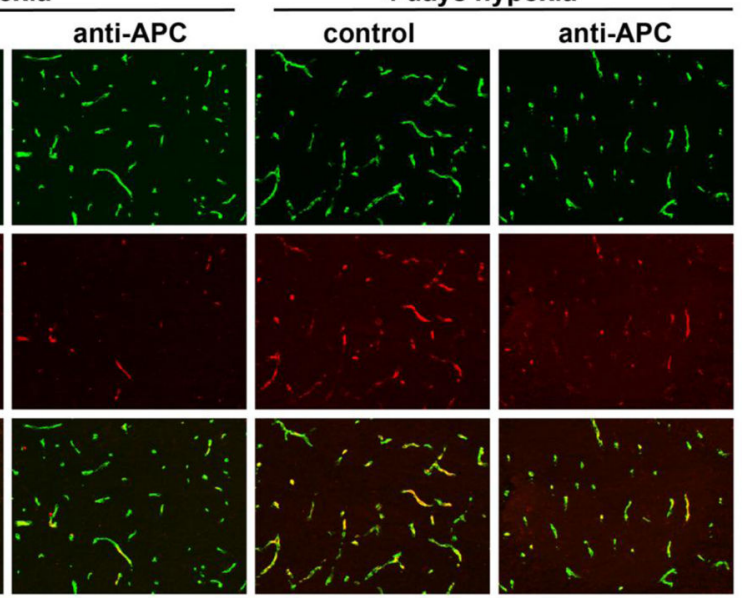

Figure 3.

Hypoxic-induced upregulation of endothelial $\beta 3$ integrin is inhibited by functional blockade of endogenous APC. A. Dual-IF was performed on frozen sections of the frontal lobe from mice exposed to 4 days normoxia or chronic mild hypoxia $(\mathrm{CMH})$ that had been injected with a monoclonal anti-APC antibody (SPC-54) or heat-denatured antibody (controls) using antibodies specific for CD31 (AlexaFluor-488, green) or $\beta 3$ integrin $(\mathrm{Cy} 3$, red). Scale bar = $100 \mu \mathrm{m}$. B. Quantification of the number of $\beta 3$ integrin-positive vessels per field. All experiments were performed with six animals per condition, and the results expressed either as the mean \pm SEM of $\beta 3$ integrin-positive vessels per field. Note that the hypoxic-induction of endothelial $\beta 3$ integrin expression was strongly inhibited by the anti-APC antibody. *** $\mathrm{P}$ $<0.005$. 

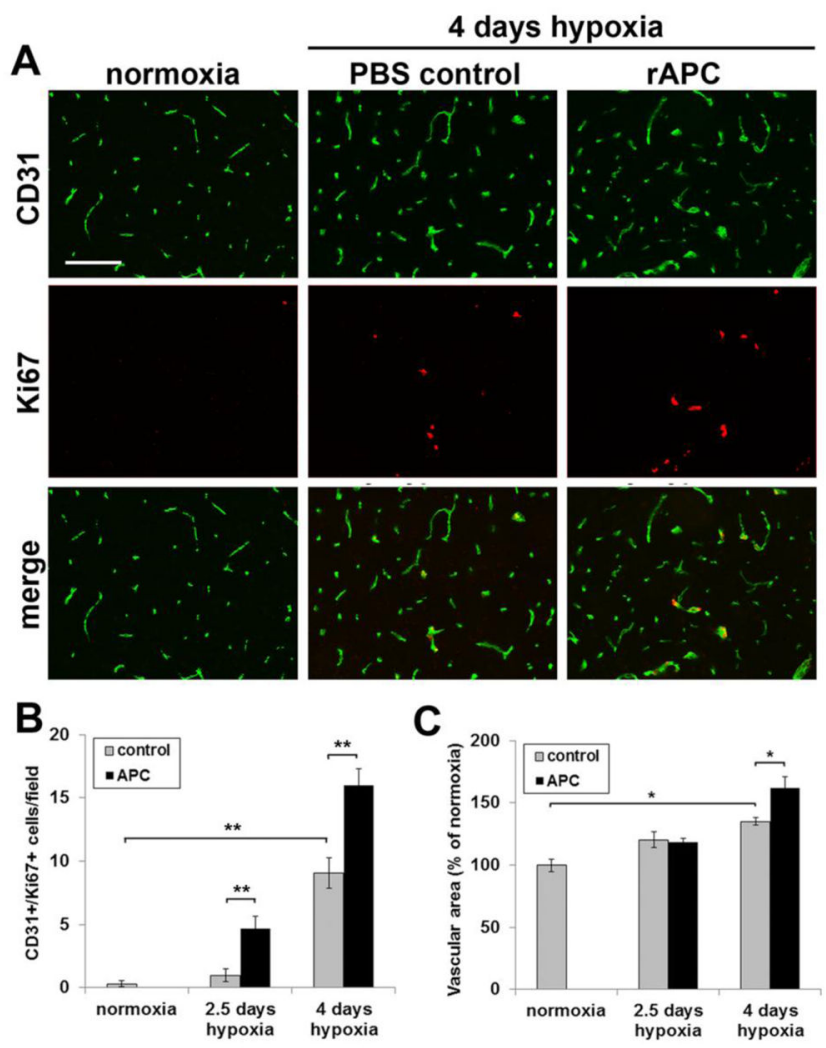

Figure 4.

Hypoxic-induced cerebrovascular remodeling is enhanced by exogenous recombinant murine APC. A. Dual-IF was performed on frozen sections of the frontal lobe from mice exposed to 4 days normoxia or chronic mild hypoxia $(\mathrm{CMH})$ that had been injected with recombinant murine APC or PBS vehicle (controls) using antibodies specific for CD31 (AlexaFluor-488, green) or Ki67 (Cy3, red). Scale bar $=100 \mu \mathrm{m}$. B-C. Quantification of the number of CD31/Ki67dual-positive cells (B) or total vessel area (C). All experiments were performed with six animals per condition, and the results expressed either as the mean \pm SEM of dual-positive cells (B) or as the mean \pm SEM of the \% change compared to normoxic conditions $(\mathrm{C})$. Note that addition of recombinant APC enhanced the hypoxicinduced increases in endothelial cell proliferation and total vascular area. $* \mathrm{P}<0.05$, ** $\mathrm{P}<$ 0.01 . 

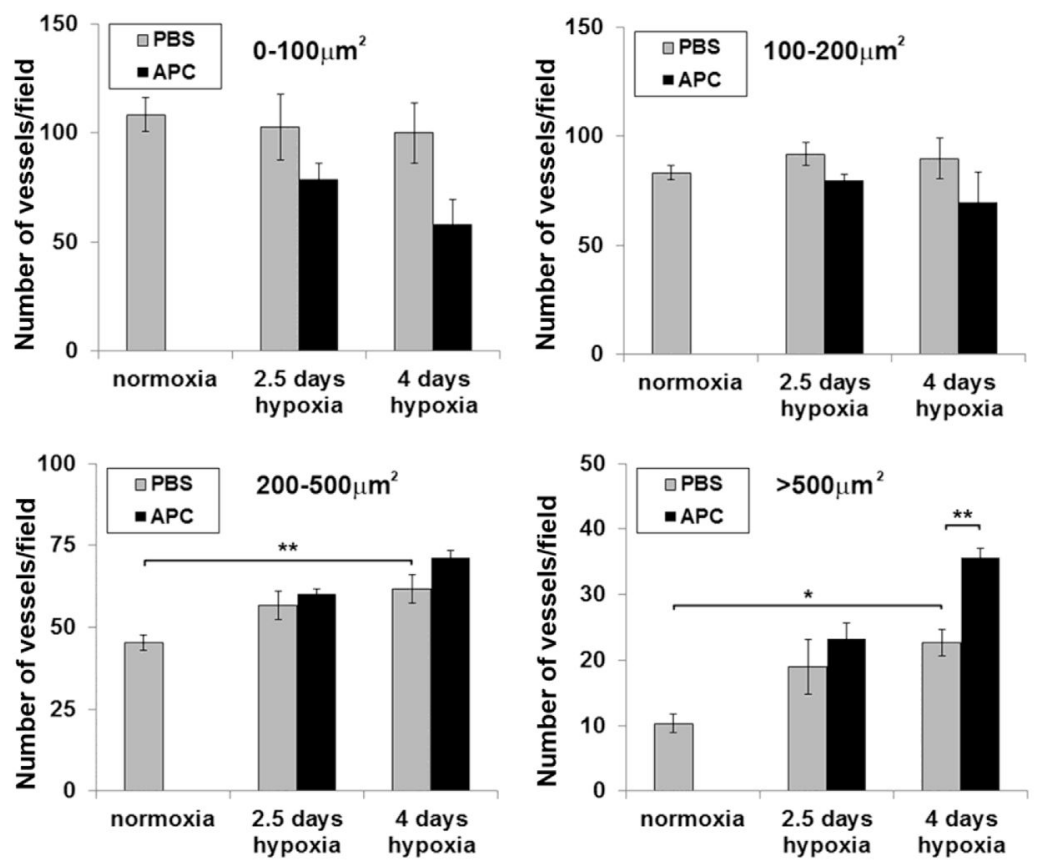

Figure 5.

Exogenous APC enhances the right-shift in vessel size distribution following chronic mild hypoxia $(\mathrm{CMH})$. Frozen sections of frontal lobe taken from mice exposed to normoxia or $\mathrm{CMH}$ for 2.5 or 4 days were immunostained for CD31, images captured, and vessel size distribution analysis performed using Volocity software. All points represent the mean \pm SEM of three subjects. Note that 4 days CMH produced a right-shift in vessel size distribution, resulting in increased numbers of large area vessels in the $200-500 \mu \mathrm{m}^{2}$ and > $500 \mu \mathrm{m}^{2}$ categories and that exogenous APC significantly increased the number of large (> $500 \mathrm{~m}^{2}$ ) area vessels, while at the same time, showing a trend towards decreasing the number of small area vessels in the $0-100 \mu \mathrm{m}^{2}$ and $100-200 \mu \mathrm{m}^{2}$ categories. $* \mathrm{P}<0.05, * * \mathrm{P}$ $<0.02$. 